\title{
Kieli on valtaa fuusioissa(kin)
}

\section{Uusia haasteita organisaatioi- den kehittämistyölle}

\author{
Janne Tienari \& Eero Vaara
}

\author{
Fuusiot yli kansallisten ja kielellisten rajojen ovat jo \\ arkipäiväiseksi käynyttä uutisantia. Ratkaisuja ja niiden \\ julkistamista tuntuvat säätelevän pörssin säälimättömät \\ lait. Mutta miten käy siinä vauhdissa pitkäjänteisen, \\ henkilöstön osaamisen kehittämiseen perustuvan \\ ajattelun? Kieli on nimittäin enemmän kuin \\ kommunikaation väline.
}

Fuusiot ja muut yritysjärjestelyt koskettavat nykyisin yhä useamman ihmisen arkipäivää. Päätöksentekijät ylittävät historiallisten valtapiirien rajoja, ja fuusioivat edustamansa yritykset suuremmiksi kokonaisuuksiksi. Erilaisten järjestelyiden ketjuissa organisaatioista näyttää tulevan väliaikaisia ja kertakäyttöisiä. Niistä näyttää tulevan "leikkaa ja liimaa” -rakenteita.

Työntekijöiden päivittäistä elämää fuusiot ja yrityskaupat koskettavat muuttuvien ammatillisten vaatimusten kautta. Organisaatioiden kehittämiseen liittyvän työn ne saattavat uudenlaisten haasteiden eteen.

Fuusiot ja yrityskaupat suuntautuvat "globalisoituvassa” taloudessa yhä useammin kansallisten rajojen yli. Työntekijöiden eteen tulee muuttuvien ammatillisten vaatimusten lisäksi uudenlaisia vaateita esimerkiksi kielitaidolle. Minkälainen merkitys kansallisuuksilla ja kansallisilla kielillä on yritysten ehdoilla "globalisoituvassa" maailmassa? Mitä haasteita kehittämistyölle kielivalinnat organisaatioissa asettavat?

Tarkastelemme seuraavassa suomalaisen Merita Pankin ja ruotsalaisen Nordbankenin fuusiota, joka julkistettiin lokakuussa 1997. Yrityk- sen ylin johto ilmoitti silloin julkisesti valitsevansa työkielekseen ruotsin. Suomalaisten keskuudessa ymmärrettiin yleisesti, että ruotsista tuli organisaation "virallinen" kieli. Merita-Nordbankenin rakentamiseen liittyvässä kehittämistyössä kielestä muodostui varsin keskeinen tekijä.

Kieli ei ole ainoastaan kommunikaation väline. Kielivalinnalla voi olla monentasoisia vaikutuksia ja merkityksiä. Kieli on valtaa.

\section{Muutos ja organisaatioiden kehittäminen}

Fuusiot ja yrityskaupat voi nähdä ilmiöinä, jotka synnyttävät "leikkaa ja liimaa" -rakenteita. Näiden rakenteiden ainoa pysyvä piirre on muutos. Kehittämisen ja muutosjohtamișen näkökulmasta tämä tarkoittaa parhaimmillaan sitä, että tavoiteltu "jatkuva kehittyminen" tai "muutosvalmius" muotoutuu organisaatioiden arkipäiväksi. Pahimmillaan voi kyse puolestaan olla siitä, että muutos- ja kehittämistyöstä tulee reaktiivista toimintaa, jota vetää eteenpäin pikemminkin yllätyksenä tulevat järjestelyt ja niiden 
synnyttämät yhdistämistarpeet kuin pitkäjänteinen, organisaation ja sen henkilöstön osaamisen kehittämiseen perustuva ajattelu.

Fuusioiden ja yrityskauppojen hallitseminen vaatii ylimmältä johdolta hyvän tarinan, joka kertoo muutoksen suunnan ja tahdin. Kuten professori Risto Tainio toteaa, hyvä tarina on lyhyt, selkeä ja kiinnostava. Se vaatii toistamista. Sen avulla omistajat ja yritysjohto keskustelevat yrityksen arvon määrittelévien "markkinoiden" kanssa. Kyse on odotusten luomisesta ja täyttämisestä.

Yritysjärjestelyiden jälkeinen yhdentyminen - integraatio - on kuitenkin johtamisosaamisen varsinainen koetinkivi. Hyvän tarinan pitää toimia myös oman talon sisällä. Käytännön toimenpiteiden tulee olla tarinan kanssa tasapainossa. Suurten muutostilanteiden myllerryksessä organisaatioiden arkisen aherruksen merkitys pääsee usein unohtumaan, kuten esimerkiksi dosentti Pauli Juuti esittää kirjassaan Johtamispuhe. Arjen monivivahteisuus ja moniäänisyys tukahdutetaan suuren tarinan tieltä.

Yhdentymisen keinot ovat fuusioissa paperilla varsin yksinkertaisia. Selkeä, välittömästi julkistettava vastuunjako erityisesti organisaation ylemmillä tasoilla on kullanarvoisen tärkeää. Laatikoiden ja nimien pitää olla heti esittelyvalmiina. Fuusiotilanteissa aina vaaniva aivovuodon mahdollisuus on tyrehdytettävä. Yhdentymissuunnitelmaan on myös sisällytettävä nopeasti saavutettavissa olevia, konkreettisia tavoitteita. Näiden tavoitteiden saavuttaminen luo onnistumisen elämyksiä ja vakaan leiman fuusioituneeseen yritykseen.

Kansalliset ja yrityskohtaiset kulttuurierot on tunnustettava, mutta niiden yli tulee jatkuvasti pyrkiä "uuteen" yhteiseen toimintamalliin. Konsulttien neuvo on, että tuleen ei saa jäädä makaamaan. Fuusiotilanteiden arki on kuitenkin vaikeaa. Fuusioita leimaa epävarmuus. Yli kansallisten rajojen ulottuvissa fuusioissa ja yrityskaupoissa yhdentymistyö on erityisen haasteellista. Tässä viitekehyksessä organisaation "virallisen” kielen valinta on keskeinen tekijä.

\section{"Fuusiomyrsky"}

Merita ja Nordbankenin fuusio vuonna 1997 oli

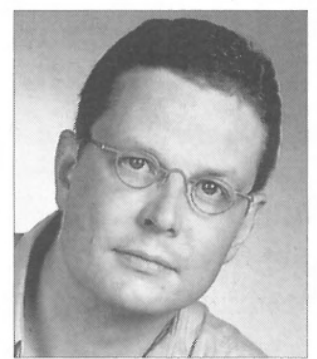

Janne Tienari

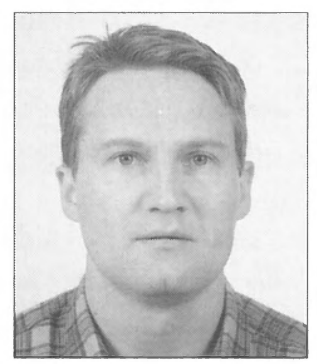

Eero Vaara

osa suurta pankkisektorin rakennemuutosta Pohjoismaissa. Nykyisin Merita ja Nordbanken ovat osa Nordea-konsernia, johon kuuluu myös tanskalainen ja norjalainen finanssilaitos sekä pienempiä pankkeja muun muassa Puolassa. Fuusioiden ja yritysjärjestelyiden ketju on ollut pitkä.

Erilaisten finanssitavaratalojen muodostuminen on uusin ilmentymä pankkimaailman muutosten ketjussa. Vanhat kansalliset valtapiirit muuttavat muotoaan. Myöskään kansalliset rajat eivät enää pidättele yritysten yhdistymisintoa. Lehdistössä on puhuttu eurooppalaisten pankkien ja vakuutusyhtiöiden "fuusiomyrskystä".

Finanssiryhmittymien globaali ulottuvuus on toistaiseksi suoraan koskettanut suomalaisia lähinnä Pohjoismaiden kautta. Erityisesti suhde ruotsalaisiin on viime aikoina joutunut suurennuslasin alle.

Uudenlaiset talouden ilmiöt herättävät henkiin perimmäisiä kysymyksiä. Suomalaisen "kulttuurin" ja identiteetin olemus asettuu uuteen valoon. Keskeistä on esimerkiksi se, mitä tapahtuu suomen kielelle suurissa kansainvälisissä fuusioissa ja yrityskaupoissa. Seuraavassa koottuja ajatuksia Suomi-Ruotsi -asetelmaan peilaten. 


\section{Kieli ei ole ainoastaan kommunikaation väline}

$\mathrm{K}$ ielikysymys ymmärretään yleensä vain tiedon välittämisen ja viestinnän kautta. Yleisen näkemyksen mukaan tärkeintä on se, että fuusion jälkeinen yhdentyminen etenee. Ja yhdentyminen etenee, kun organisaatiossa kommunikoidaan riittävästi.

Kun kahta eri kansallista alkuperää edustavat yritykset fuusioituvat, on kielivalinnoille organisaation sisällä kolme perusvaihtoehtoa. Kaikissa vaihtoehdoissa on tietenkin periaatteena se, että asiakas saa omalla maaperällään aina palvelua omalla kielellään.

Ensinnäkin, kielikysymys voidaan sivuuttaa olankohautuksella: "kaikki käy” ja kulloisenkin tilanteen tarve määrittelee millä kielellä toimitaan. Tavoitteena on toiminnallinen joustavuus ja avoin kommunikaation pelikenttä.

Toiseksi, jos kieleksi valitaan toisen fuusioituneen yrityksen kansallinen kieli, tavoitteena on linjakkuus. Näin voidaan myös saavuttaa merkittäviä säästöjä esimerkiksi käännöstyön kustannuksissa.

Kolmanneksi, kielivalinta voi myös olla "kompromissi", jokin laajalle levittäytynyt maailmankieli. Pankkitoiminnassa tämä maailmankieli - lingua franca - on yleensä englanti. Kompromissiratkaisu henkii tasa-arvoa ja kansainvälisyyttä. Organisaatiossa korostuu kansainvälisesti suuntautuneiden ihmisten asema.

Kielikysymys on fuusion neuvottelu- ja valmisteluvaiheessa liian usein vain yksi ratkaisua vaativa käytännön asia muiden joukossa. Kielikysymyksestä voi tulla pelinappula ja neuvotteluiden jakojäännös.

Kielen vähättelyssä on kuitenkin vaaransa. Kieli ei ole ainoastaan ihmisten välistä kanssakäymistä edesauttava tai haittaava tiedon välittämisen ja viestinnän väline.

$\mathrm{S}$ uomalaisten ja ruotsalaisten välinen suhde on monimutkainen. Yhtäältä on ilmeistä, että tämä suhde kantaa historian perintöä. Perintö on ainutlaatuinen - niin kuin kaikki eri kansojen väliset suhteet. Perintöä ruokkivat erilaiset ennakkokäsitykset ja stereotypiat.

Suomi oli satoja vuosia osa Ruotsin kunin- gaskuntaa. Suomalaisella puurtajalla on ollut tapana suhtautua ruotsalaisiin lähetyssaarnaajiin alistuvan epäilevästi. Ruotsalainen puolestaan pitää tällaista epäluuloisuutta ihmeellisenä. Lopputulema on, että Suomi on Ruotsiin nähden ikuinen "pikkuveli”. Näin siis henkisessä mielessä.

Toisaalta nykyisin voidaan jopa puhua läheisyyden harhasta. Kun maantieteellisesti läheisistä maista tulevat ihmiset ovat keskenään kanssakäymisessä, riski kulttuurisille väärinkäsityksille on erityisen suuri. Samankaltaisuudet toimintatavoissa otetaan itsestäänselvyyksinä ja eroja aliarvioidaan.

Suomalaisten ja ruotsalaisten välillä on kuitenkin ainakin yksi keskeinen organisatorisia käytäntöjä ohjaava ero. Tämä ero kuulostaa kliseeltä, mutta se jaksaa yhä edelleen hämmästyttää suomalais-ruotsalaisten fuusioiden toteuttajia.

Suomalaisille aika on rahaa. Nopea ja jämäkkä päätöksenteko on hyve. Ruotsalaisille aika on laatua. Perinpohjaisesti keskusteltu ja valmisteltu päätöksenteon prosessi on hyve. Nämä käytännön toiminnassa heijastuvat erot eivät ole yksiselitteisesti yhdennytettävissä.

Kun tällaiset kulttuuriset erot yhdistyvät kysymykseen kielestä, vyyhti on entistä monisäikeisempi. Kielellä on monikansallisessa ympäristössä viestinnän ja kommunikaation ohella monenlaisia vaikutuksia. Kieli rakentaa organisaation valtasuhteita.

Kyky käyttää kieltä on organisaation päivittäisessä elämässä yksittäisille ihmisille vallan lähde ja väline. Kieli on keskeinen tekijä yksilöiden ja ryhmien osaamisen ja ammatillisen identiteetin rakentumisessa tai murenemisessa. Kielellä on myös symbolista merkitystä.

\section{Kehittämistyötä kielivalinnan varjossa}

$\bigvee_{\text {tömästi fuusioilmoituksen jälkeen näke- }}^{\text {erita-Nordbankenin ylin johto esitti välit- }}$ myksensä yhdentymistyön merkityksestä organisaation eri tasoilla. Uuden "kulttuurin" rakentamisen tuli perustua olemassa oleviin parhaisiin käytäntöihin Pohjanlahden molemmin puolin.

Suomalaiset tekivät pelinavauksen kulttuurikeskusteluihin Merita-Nordbankenissa. Heillä oli tällaisesta yhdentymistyöstä kokemusta. Kun Kan- 
sallispankki ja Suomen Yhdyspankki yhdistyivät Merita Pankiksi 1995, pankin ylin johto ja henkilöstön kehittämisen asiantuntijat loivat organisoidut puitteet kahden erilaisen "pankkikulttuurin" kohtaamiselle. Meritassa toteutettiin ohjattujen vuoropuheluiden sarja.

Koppilaiset ja syppiläiset pohtivat seminaareissa käsityksiään itsestään, toisesta ja yhteisestä tulevaisuudesta. Vaikka kulttuurikeskustelut toivat monta kipeää asiaa esille, keskustelemattomuus olisi ollut huonompi vaihtoehto. Tosiasioiden - tässä tapauksessa erojen - tunnustaminen oli viisauden alku. Sama perusajatus monistettiin Meritan ja Nordbankenin fuusiossa.

Meritan henkilöstön kehittämisyksikössä Tanskarlassa järjestettiin pilottiseminaarin jälkeen huhti-lokakuun 1999 välisenä aikana 18 yrityskulttuuriseminaaria. Kuhunkin seminaariin osallistui kahden suomalaisen ja kahden ruotsalaisen yksikön edustajia. Osallistujat työskentelivät joko yrityksen keskijohdossa tai asiantuntijatehtävissä.

Apulaisjohtaja Risto Säntti Meritan henkilöstön kehittämisosastolta oli vastuussa uuden pankin kulttuurikoulutuksesta ja kielipolitiikasta. Hänen mukaansa kulttuurin käsite auttoi seminaarien osallistujia jäsentämään monimutkaista yritysympäristöä. Osallistujien tehtävänä oli yhtäältä välittää kentän viestejä yhdentymistyöstä pankin ylimmälle johdolle sekä toisaalta jakaa seminaarikokemuksiaan omien yksiköidensä päivittäisen työn lomassa.

Kulttuuriseminaarien tavoitteena oli auttaa ihmisiä ymmärtämään "toisen osapuolen" tapaa toimia. Tavoitteena ei ollut välittömästi muuttaa vakiintuneita toimintatapoja. Seminaarityöskentelyn avainsanaksi muodostui käytännönläheisyys.

Pankissa huomattiin varsin pian kielen merkitys organisaation arkea ohjaavana tekijänä. Ruotsin kielen korostuneen aseman mukanaan tuomat haasteet löivät leimansa myös kulttuuriseminaarien työskentelytapoihin ja sisältöön. Eräs keskeisimmistä viesteistä pankin ylimmälle johdolle oli kielivalinnan ongelmallisuus.

\section{Organisatorinen kommuni- kaatio ja yksilöiden valta}

Jos ruotsalais-suomalaisen yrityksen "virallisek- si” kieleksi tulkitaan ruotsi, lienee itsestäänselvää, että ruotsia äidinkielenään puhuvat ihmiset ovat niskan päällä päivittäisessä kanssakäymisessä suomenkielisten kanssa. Tämä voi näkyä tiedostamattomana tai tietoisena vallankäyttönä.

Yleensä ne, joille jakautuu vähiten valtaa ovat vallan epätasaisesta jakautumisesta eniten tietoisia. Ne, joille valta kielivalinnan kautta tulee ulottuville, vähättelevät yleensä kielen merkitystä.

Valta ei tässä viittaa organisatorisen aseman mukanaan tuomaan "viralliseen" valtaan esimerkiksi päätöksentekovaltuuksien muodossa. Se viittaa "epäviralliseen", sosiaalisiin suhteisiin ja verkostoihin kiinnittyvään valtaan. Tieto on valtaa ja valta on tietoa. Kielitaito puolestaan edesauttaa linnoittautumista tiedon ja vallan välittymisen solmukohtiin.

On myös huomattava, että fuusioituvan yrityksen ylimmillä johtotasoilla on suuri kiusaus aliarvioida tietyn kansallisen kielen valinnan aiheuttamia kustannuksia. Yrityksessä käytössä olevat tilastot työntekijöiden kielitaidosta perustuvat subjektiivisille ja usein vanhentuneille arvioille. Suomi-Ruotsi -asetelmassa ruotsin kielen todellinen koulutustarve voi olla moninkertainen arvioituun verrattuna.

Epätyydyttävästi ruotsia puhuvalla suomenkielisellä organisaation jäsenellä on kuvatunlaisessa fuusiotilanteessa useita vaihtoehtoisia selviytymisstrategioita. Hän voi käyttää hyväkseen yrityksen koulutustarjontaa ja harjoittaa kielitaitoaan myös päivittäisen työpanoksensa ulkopuolella. Hän voi paeta organisaation sisällä yksikieliseen yksikköön; pankeissa esimerkiksi sivukonttoriverkostoon. Hän voi hakeutua organisaation ulkopuolelle. Hän voi jatkaa päivittäistä työtään kielitaitonsa rajoissa kuin mitään ei olisi tapahtunut. Hän voi lähteä "vastavallankumoukseen” ja kehitellä liittolaistensa kanssa suomesta salakielen esimerkiksi neuvottelu- ja kokoustilanteissa.

Ruotsia äidinkielenään puhuvat suomalaiset taas joutuvat suomalais-ruotsalaisissa fuusioissa outoon asemaan. Heidän ensireaktionsa ruotsinkielen aseman korostumiseen ovat todennäköisesti myönteisiä. Erityisesti organisaation alemmilla tasoilla ruotsinkieliset voivat kuitenkin ajautua aikaa myöten kiusalliseksi muodostuviin erityistehtäviin. He voivat joutua erilaisiin kään- 


\section{PUHEEN V U ORO}

nöstehtäviin varsinaisten tehtäviensä ohella. Sanavalinta- ja ääntämiserot suomenruotsin ja riikinruotsin välillä kruunaavat heidän oudon asemansa. Riikinruotsalaiset voivat olla herkkiä tulkitsemaan nämä erot laatueroiksi.

\section{Ammatillinen identiteetti}

$\mathrm{K}^{\mathrm{i}}$ eli nivoutuu myös käsityksiin osaamisesta ja mmatillisesta pätevyydestä. Vieraalla kielellä toimiminen ja selviytyminen voi tyrehdyttää ammattikielen ja -termistön tarkoituksenmukaisen hyödyntämisen. Myös kielelliset taidot kuten argumentointi, suostuttelu ja neuvotteleminen vaikeutuvat.

Kauhuskenaario on, että kansainvälisyyteen esimerkiksi englannin kielen kautta oppinut suomalainen vaikenee jälleen kahdella kielellä. Hän vaikenee, koska häpeää “minä Tarzan, sinä Jane” -ruotsiaan.

Vaihtoehtona vaikenemiselle on valvoa aktiivisesti omia etuja. Periaatteena on tässä se, että ruotsinkielisille ei anneta kielellistä ja ammatillista yliotetta - ja siten vallan avaimia - päivittäisessä työssä. Suomenkielinen voi vaihtaa "baariruotsinsa” englantiin kun ryhdytään puhumaan asiaa. Tässä vaihtoehdossa suomenkielinen on kuitenkin loppujen lopuksi aina ruotsinkielisten kollegoidensa ymmärtämyksen ja hyvän tahdon armoilla. Valtasuhde ei ole lähtökohtaisesti tasapainossa.

Kieli saattaa myös aiheuttaa epävarmuutta henkilökohtaisesta urakehityksestä. Kun oma ammattitaito ei kieleen liittyvien tekijöiden takia välity oikeille henkilöille, uusien työtehtävien ja haasteiden löytäminen voi kohdata esteitä.

\section{Kielen symboliset ulottuvuudet}

Сuusioituvan yrityksen kielivalinta ei ole ai1 noastaan yrityksen sisäinen asia. Tämä käy selvästi ilmi esimerkiksi siitä, miten tiedotusvälineet uutisoivat ja kommentoivat kansalliset rajat ylittäviä fuusioita. Kielikysymyksen mukaan tuomista valta-asetelmista on kielen symbolinen merkitys kenties mielenkiintoisin.

Suomalaiset tiedotusvälineet ovat usein kärkkäitä samaistamaan fuusion suomalaista osapuol- ta edustavan yrityksen ja Suomen. Näin myös kielivalinta symbolisoi Suomen asemaa fuusioituvassa yrityksessä.

Media rakentaa ja uusintaa erityistä kansallista diskurssia, jossa eri kansojen välisiin suhteisiin kiinnittyvät ennakkokäsitykset ja stereotypiat uudistetaan yhä uusissa yhteyksissä. Tällainen kansallinen diskurssi voi ammentaa esimerkiksi urheilusta tai sodankäynnistä.

Fuusioitunut yritys voidaan korottaa Suomen edustajaksi maaotteluun. Muutama esimerkki lehtiotsikoista Merita Pankin ja Nordbankenin välisen fuusion alkutaipaleelta havainnollistaa tätä: “Organisaatiopelissä Suomelle 6-5 tappio” (Kauppalehti), “Liiketoimintayksiköt: Ruotsi 3, Suomi 2” (Ilta-Sanomat), "Tilanne maaottelussa Suomi-Ruotsi näyttää olevan 0-1" (Helsingin Sanomat) ja "Maaotteluhenki elää sitkeästi" (Talouselämä).

Toinen suosittu kansallisen diskurssin aihepiiri on sodankäynti. Kun esimerkiksi Helsingin Sanomien toimittaja kommentoi kolumnissaan Merita-Nordbankenin tekemiä kauppoja Pohjolan osakkeista ruotsalaisen vakuutusyhtiö Skandian kanssa, hän rinnasti pankin suomalaisen nokkamiehen Vesa Vainion seuraavasti: “toukokuun 5. päivänä 1808 vara-amiraali Carl-Olof Cronstedt luovutti Viaporin venäläisille ilman mittavia taisteluita."

Vanhat kansojen välisiin suhteisiin liittyvät ylemmyys-alemmuus -asetelmat heräävät henkiin nykypäivän kansainvälisissä fuusioissa. Kun suomalais-ruotsalaisen organisaation kieleksi valitaan ruotsi, tämä voidaan julkisuudessa tulkita signaaliksi ruotsalaisten uudesta valloitusretkestä Suomen maaperälle. Ja median luoma "todellisuus” heijastuu fuusioituvan yrityksen sisälle.

Kaiken kaikkiaan, jos toisen kansallisen kielen valitsemisella fuusioituvan yrityksen kieleksi on näin laajat ja monimuotoiset vaikutukset, onko siis kielellinen "kompromissi" ratkaisun avain?

\section{Myöskään englanti ei ole neutraali kieli}

$\mathrm{B}$ riteillä on monia vähemmän mairittelevia termejä ulkomaalaisten puhumalle englannin kielelle. Ääntämykseltään kömpelöä ja sana- 
valikoimaltaan tarkoituksenmukaisen suppeaa kieltä voidaan kutsua esimerkiksi nimillä "broken English" (rikkinäinen englanti) tai "pigeon English" (kyyhkysenglanti). Englannin kielen versioista on kuitenkin kehkeytynyt globaalin tai ainakin länsimaisen - talouden maailmankieli.

Englannin kieli voi fuusioituvassa yrityksessä olla alusta asti tietoinen valinta. Englanti voi myös luonnollistua ratkaisuksi kommunikaatioon, kuten edellä esitetty "baariruotsin" ja ammatillisen identiteetin esimerkki antaa ymmärtää.

Erityisesti tietoisen valinnan tapauksessa korostuu kansainvälisesti suuntautuneiden organisaation jäsenten asema. Englantia äidinkielenään puhuvat tietenkin hyötyvät valinnasta. Englannin kielestä voi myös tulla valtaeliitin kieli - ja kansalliset kielet säilyvät operatiivisen toiminnan kielenä.

Näennäisesti neutraali englannin kieli rakentaa siis valta-asetelmia, aivan kuten yllä tarkasteltu ruotsin kieli. Englannin kielen korostumisella on syvällisiä seurauksia. Paikalliset (esimerkiksi Suomi) tai alueelliset (esimerkiksi Pohjoismaat) tavat ja käytännöt korvautuvat "universaaleilla" ja "globaaleilla".

Nämä "universaalit" ja "globaalit" tavat ja käytännöt kuitenkin heijastavat juuri tietynlaista käsitystä todellisuudesta. Tämä käsitys on angloamerikkalainen uusi kapitalismi. Kun kansainvälisen finanssiyhteisön englannin kielisen slangin merkitys kasvaa, anglo-amerikkalainen kulttuurinen standardisointi - tai uuden kapitalismin suuri tarina - etenee. Kaikki eivät tätä kuitenkaan niele purematta, kuten ranskalaisten ylpeä esimerkki osoittaa.

\section{Fuusioketju jatkuu}

Yritysfuusioiden määrän rajun maailmanlaajuisen kasvun kerrotaan hidastuneen viimeksi kuluneen vuoden aikana. Suunnannäyttäjänä "fuusiomyrskyn" laantumisessa on ollut telekommunikaatioala. Vedenjakajana oli kevään 2000 aikana puhjennut uuden talouden yritysten pörssikupla.

Uuden talouden puuhamiesten "tarinat"

Taulukko 1: Kieli kansainvälisessä fuusiossa

\begin{tabular}{|c|c|c|c|}
\hline & \multicolumn{3}{|c|}{ VAIKUTUS VALTASUHTEISIINORGANISAATIOSSA } \\
\hline KIEIJVALINTA & Kommunikaatio & Ammatillinen identiteetti & Symboliset merkitykset \\
\hline "Kaikki käy" & $\begin{array}{l}\text { Avoin pelikenttä. } \\
\text { Voi syntyä kulttuuris- } \\
\text { poliittisia saarekkeita. }\end{array}$ & $\begin{array}{l}\text { Avoin pelikenttä } \\
\text { Erityisosaaminen voi } \\
\text { korostua }\end{array}$ & $\begin{array}{l}\text { Valtapeli on kesken/ } \\
\text { jatkuu. }\end{array}$ \\
\hline $\begin{array}{l}\text { Yksi kansallisista } \\
\text { kielistä }\end{array}$ & $\begin{array}{l}\text { Kielen osaajien asema } \\
\text { vahvistuu sisäisessä } \\
\text { kommunikaatiossa } \\
\text { (ja päätöksenteossa). }\end{array}$ & $\begin{array}{l}\text { Sisäänrakennettu amma- } \\
\text { tillinen epätasa-arvo } \\
\text { (ilmenee esim. johtamis- } \\
\text { tai neuvottelutaitona. }\end{array}$ & $\begin{array}{l}\text { Yhtenäiskulttuuri rakentuu } \\
\text { toisen osapuolen ehdoilla. } \\
\text { Ylemmyys ja alemmuus } \\
\text { eri osapuolten välillä. }\end{array}$ \\
\hline $\begin{array}{l}\text { Lingua franca } \\
\text { (esim. englanti) }\end{array}$ & $\begin{array}{l}\text { Kansainvälisesti suun- } \\
\text { tautuneiden asema } \\
\text { korostuu. }\end{array}$ & $\begin{array}{l}\text { Kansainvälinen profes- } \\
\text { sionaalistuminen vah- } \\
\text { vistuu ja sitä arvostetaan. } \\
\text { Kansainvälisen ammatti- } \\
\text { yhteisön slangin merkitys } \\
\text { kasvaa. }\end{array}$ & $\begin{array}{l}\text { Tasa-arvo korostuu. } \\
\text { Kulttuurinen } \\
\text { standardi etenee. }\end{array}$ \\
\hline
\end{tabular}


ovat yhä useammin kääntyneet itseään vastaan. Kun on tullut luotujen odotusten täyttämisen paikka, toiminnalliset näytöt ovat jääneet vähiin. Hyvä erottuu yhä selvemmin huonosta. Liiketaloudellisesti järkevät fuusiot ja yrityskaupat alkavat erottua epämääräisistä, lyhyen tähtäimen arvonnousuun perustuvista viritelmistä.

Monilla muilla aloilla kansainväliset fuusiot ja yritysjärjestelyt ovat edelleen ajankohtaisia. Esimerkiksi eurooppalaisten pankkien ja vakuutusyhtiöiden kansallisten rajojen yli raivoava "fuusiomyrsky” näyttää jatkuvan. Nykyfuusiot perustellaan yleensä suuruuden kauneudella ja synergiaeduilla. Näitä etuja lienee Euroopassa vielä viljalti hyödyntämättä.

Kun Merita-Nordbanken ilmoitti fuusiostaan tanskalaisen Unidanmarkin kanssa maaliskuussa 2000, ylin johto teki heti selväksi, että uuden konsernin "virallinen" yhteinen kieli tulee olemaan englanti. Konsernin ytimeen kuuluu nykyisin myös norjalainen Christiania Bank og Kreditkassen. Uuden Nordean pohjoismaista identiteettiä pyritään rakentamaan kielellisesti tasaarvoiselta pohjalta.

\section{Erot elävät ja voivat hyvin}

A lbert Einsteinin kerrotaan aikoinaan tokaisseen: “jos minun suhteellisuusteoriani osoittautuu paikkansa pitäväksi, Saksa väittää minua saksalaiseksi ja Ranska maailman kansalaiseksi. Jos teoriani osoittautuu paikkansa pitämättömäksi, Ranska kutsuu minua saksalaiseksi ja Saksa julistaa minut juutalaiseksi."

Kansainvälisissä fuusioissa on edelleen sisäänrakennettuna kansallinen elementti. Kansalliset identiteetit ja intohimot elävät ja voivat hyvin myös nykyisessä "globaalissa" taloudessa. Kieli määrittää edelleen näitä identiteettejä ja intohimoja.

Mitä ajatuksia Merita-Nordbankenin kielivalinta ja sitä seurannut kehittämistyö voi siis Aikuiskasvatus-lehden lukijoille tarjota? Tarkoituksellisella toiminnalla on ei-tarkoituksellisia seurauksia, kuten tunnettu sosiologi Anthony Giddens on esittänyt. Merita-Nordbankenin kielivalinta voidaan nähdä oivana esimerkkinä siitä, miten fuusioratkaisu synnyttää tällaisia seurauksia.

Tässä tapauksessa pragmaattiseksi tarkoitettu päätös ruotsin kielen valinnasta organisaation ylempien tasojen työkieleksi käynnisti muutosprosessin, jota oli vaikea ennakoida ja usein rajallisesti mahdollista hallita. Pankin johdon näkökulmasta kyse oli yhtäältä kyvystä vastata yhtäkkiä syntyneeseen ruotsin kielen koulutustarpeeseen sekä rakentaa kehittämisohjelmaa "kulttuurien” väliseen kanssakäymiseen. Toisaalta syntyi akuutti tarve yrittää hallita kielivalinnan synnyttämiä kielteisiä mielikuvia organisaation sisällä ja ulkopuolella.

Arjen ääni voi joskus olla niin vahva, että se haastaa suuret tarinat. Vaikka "leikkaa ja liimaa" -rakenteet muuttuvat, ihmiset organisaatioiden sisällä eivät ole kertakäyttötavaraa. Kehittämistyön haasteisiin on yhä vaikeampi varautua etukäteen.

Kirjoitus perustuu työpaperiin "Language as Power in Postmerger Integration: The Case of Merita-Nordbanken" (Eero Vaara, Janne Tienari, Risto Sänttti ja Rebecca Marschan-Piekkari), joka esitettiin konferenssissa $26^{\text {th }}$ Annual Conference of the European International Business Academy (EIBA), Maastricht, Alankomaat, 10-12 joulukuuta 2000.

\section{Teoreettisia lähtökohtia}

ALVESSON, M. ja BERG P.O. (1988): Företagskultur och organisationssymbolism - utveckling, teoretiska perspektiv och aktuell debatt. Lund: Studentlitteratur.

GIDDENS, Anthony (1984): The Constitution of Society. Cambridge: Polity Press.

HABECK, M., KRÖGER, F. ja TRÄM, M.R. (2000): After the Merger: Seven Rules for Successful Post-Merger Integration. London: Financial Times / Prentice Hall.

JUUTI, Pauli (2001): Johtamispuhe. Aavaranta-sarja no 48. PS-kustannus, Juva.

KOISTINEN, Heli (2000): Yrityskulttuuriseminaarien suunnittelu- ja toteutusprosessi henkilöstön kehittämisyksikön toimintana. Pro gradu -tutkielma, Helsingin yliopisto / Kasvatustieteen laitos.

KURONEN, Marja-Liisa, Tienari, Janne ja Vaara, Eero (2000): "Päättyykö Meritan viidakkoretki?": kielitieteilijän ja organisaatiotutkijan tulkintaa muutoksen sosiaalisesta rakentumisesta tiedotusvälineissä. Virittäjä 4/2000, 518-543.

SÄNTTI, RISTO (2001): How Cultures Interact in an International Merger - Case MeritaNordbanken. Väitöskirja, Tampereen Yliopisto / Ammatillinen opettajakorkeakoulu.

TAINIO, RISTO (2000): Omistus- ja johtamisstrategiat tulevaisuuden Euroopassa. Liiketaloudellinen Aikakauskirja 1, 158-172.

TIENARI, Janne, Vaara, Eero ja Kaihua, Katja (1999): Talouden diskurssien uusintamisen jäljillä - eli miten yritysjärjestelyä käsitellään suomalaisessa lehdistössä. Hallinnon Tutkimus 3, 232-250. 